\title{
AN EXPERIENTAL INVESTIGATION OF EFFECT OF CUTTING PARAMETERS AND TOOL MATERIALS ON TOOL LIFE AND PRODUCTIVITY IN TURNING OF CYLINDER LINERS
}

\author{
Prasanna P Kulkarni ${ }^{1}$, Vinayak koppad ${ }^{2}$, Hemanthkumar.K.S ${ }^{3}$ \\ ${ }^{1}$ Lecturer, Dept of Mech. Engg., Sri Taralabalu Jagadguru Institute of Technology Ranebennur, Karanataka, India \\ ${ }^{2}$ Lecturer, Dept of Mech. Engg., Sri Taralabalu Jagadguru Institute of Technology Ranebennur, Karanataka, India \\ ${ }^{3}$ Lecturer, Dept of Mech. Engg., Sri Taralabalu Jagadguru Institute of Technology Ranebennur, Karnataka, India
}

\begin{abstract}
The major needs of machining are high material removal rate, good work surface finish and low tool wear. Industries are hiring to increase economical benefits by reducing the cost of production. These objectives can be achieved by using proper cutting tool material and cutting parameters. This report presents comparisons of two different coated carbide inserts under different cutting parameters used during machining of cylinder liners made up of grey cast iron. The comparison has been realized through the tool life tests and productivity. The measurement has been carried out from rough boring operation at three cutting speed $\left(V_{c}\right)$ and feed rate (f). Depth of cut (doc) is kept constant at $1.5 \mathrm{~mm}$. Cutting tool used in this work is titanium nitride (TiN) coated carbide and comparing with Multilayer coated tool is titanium nitride $(\mathrm{TiN})+$ titanium carbo nitride $(\mathrm{TiCN})+$ Aluminium oxide $\left(\mathrm{Al}_{2} \mathrm{O}_{3}\right)$ coated carbide inserts. The type of the insert is $S N M G$ 120408. Cutting conditions used is speed $\left(V_{c}\right) 100 \mathrm{~m} / \mathrm{min}, 125 \mathrm{~m} / \mathrm{min}, 150 \mathrm{~m} / \mathrm{min}$. Feed rate (f) $0.25 \mathrm{~mm} / \mathrm{rev}, 0.3 \mathrm{~mm} / \mathrm{rev}, 0.35 \mathrm{~mm} / \mathrm{rev}$. Finally results of the present work determine the appropriate parameter for increasing the tool life, and productivity.
\end{abstract}

Key words: Tool life, Coated tool material, Process parameters, Productivity.

\section{INTRODUCTION}

The cylinder liners usually made from Grey cast iron. Cast iron has been used in large quantities for years because of desirable properties as good cast ability, good machinability and low cost. A wide variety of Gray Cast Iron is used in industries for various applications. Machinability of Cast Iron is affected by the amount of carbon [3]. Cast iron has been used in large quantities for years because of desirable properties as good cast ability, good machinability and low cost. This is brittle, weak and is not malleable. A wide variety of Gray Cast Iron is used in industries for various applications. Machinability of Cast Iron is affected by the amount of carbon. It has excellent machinability, good wear resistance, and high vibration absorption. Grey iron is valued particularly for its ability to be cast into complex shapes at relatively low cost. Thus, its application includes: Sanitary wares, household appliances, rolling mill and general machinery parts, ingot moulds, cylinder blocks and heads for I.C. engines, frames for electric motors, machine tool structures, etc.

Increasing the productivity and quality of the machine parts are the main challenges of manufacturing industries. Modern cutting tool allow cutting at high speeds, thus increasing the volume of chips removed per value of unit time. The objective of machining is to produce high quality product with minimum cost. Development of tool material plays very vital role to achieve this objective and to cope up with high speed cutting (HSC). The purpose of development of cutting tool material has different advantages such as reducing the manufacturing cost and lead time, machining more difficult materials, moving to unmanned machining operations, improving surface integrity and achieving high metal removal rates [2]. The advantage of high speed machining is not only to reduce machining cost by increasing metal removal rate but also yields good surface quality of machined parts [2].

The cost of replacing cutting tools is a major slice of the total running cost of the manufacturing industries. It is therefore desirable to have cutting tools that can be used for a long time before being replaced. This can be achieved either by making cutting tools from more wear resistant materials or through the selection of machining conditions that will result in lower tool wear. The use of cutting tools made of wear resistant materials invariably increases the operating cost; a lower material removal rate may result in lower productivity, making the final products uncompetitive. The ideal situation would be one where a desirable productivity is attained at an acceptable rate of tool wear.

Carbides are the most prevalent tool materials, they are tough and they can be used for machining using high feed rate, speed and for difficult intermittent machining. Coated carbides consist of a hard carbide base and coating which increases the thermo-chemical stability (carbides, nitrides, oxides and their combinations).

Carbide cutting tools are widely used in metal cutting industry for the cutting of various hard materials such as alloy steels, die steels, white cast iron and graphite cast iron. During machining coated carbide tools are ensure higher wear resistance, lower heat generation and lower cutting forces, thus 
enabling them to perform better at higher cutting conditions than their uncoated counter parts. Coating is also used on cutting tools to provide improved lubrication at the tool/chip and tool/workpiece interface and to reduce friction, and consequently reduce the temperature at cutting edge.

Quality of the machined component is an important index of machinability for evaluating the productivity. Usually, the cutting parameters are selected based on experience or a handbook (Yang \& Tarng, 1998) by engineer but it does not yield the accurate results. Therefore, in turning process, it is important task to select cutting parameters for achieving high cutting performance, which greatly influences manufacturing cost. An optimum selection of cutting conditions is extremely important. In order to predict surface quality in advance, it is important to develop theoretical models. Yang and Tarng (1998) had used the Taguchi method to find the optimum cutting parameters for turning operations as reported in paper [2]. There have many studies concerning the effect of cutting parameters and tool geometry on the cutting forces the influence of machining parameters such as cutting speed, feed rate, depth of cut for different materials[14]

The present work deals with experimental investigation on tool life, surface roughness of grey cast iron using different coated carbide inserts with different levels of process parameters. Machining tests carried out on greaves cylinder blocks produced from grey cast iron having areas involving grooves (with interrupted surface) used in automotive industry. This report presents the result of a Cycle time is considered as the major aspect to be minimized to enhance the high productivity. The influence of the machining parameters and tool material on the tool life is also investigated and the optimum cutting condition for minimizing the cycle time to enhance the productivity is investigated.

\section{EXPERIMENTAL DETAILS}

In the present experimental test were performed on the cylinder liners made by grey cast iron. Coated carbide inserts are used as tool materials. Titanium nitride coated carbide and Titanium nitride + Titanium carbonitride + Aluminium oxide coated carbide are used as tool materials.

\subsection{Work Material}

Cylinder liners made from grey cast iron is used as work material. Since it is most commonly used grade in the automotive industries. The cylinder liners of size $\varnothing 80 \times 137 \mathrm{~mm}$ length were used for the present investigation. Fig. 1 shows the cylinder blocks before machining and after machining. The chemical composition of the material is shown in the Table 1.

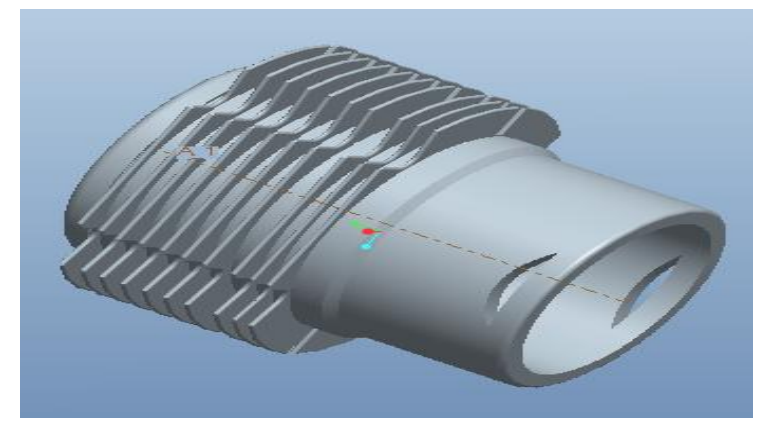

Fig. 1: Work piece

Table -1. Chemical composition of grey cast iron (Greaves cylinder)

\begin{tabular}{|c|c|c|c|c|c|c|c|}
\hline $\begin{array}{l}\text { ALLOYING } \\
\text { ELEMENTS }\end{array}$ & C & $\mathrm{Si}$ & $\mathrm{Mn}$ & $\mathrm{Cr}$ & $\mathrm{Ph}$ & Su & $\mathrm{Cu}$ \\
\hline$\% \mathrm{wt}$ & $\begin{array}{c}3.00 \\
- \\
3.50\end{array}$ & $\begin{array}{c}1.90 \\
- \\
2.20\end{array}$ & $\begin{array}{c}0.45 \\
- \\
0.65\end{array}$ & $\begin{array}{c}0.30 \\
- \\
0.50\end{array}$ & 0.10 & 0.05 & $\begin{array}{c}0.30 \\
- \\
0.60\end{array}$ \\
\hline
\end{tabular}

\subsection{Selection of Cutting Tool materials}

The turning tests were conducted using coated cemented carbide cutting tool with negative rake angle and 0.8 nose radius. CVD coated Carbides with the specification SNMG 120508-GN (with an ISO designation), TiN coated (TT1300) \& $\mathrm{TiN}+\mathrm{TiCN}+\mathrm{Al}_{2} \mathrm{O}_{3}$ (Multilayer coated IC5010) inserts shown in Fig.2a and Fig.2b. Tool holder which is specially used for SNMG inserts for boring operation shown in Fig. 2c.

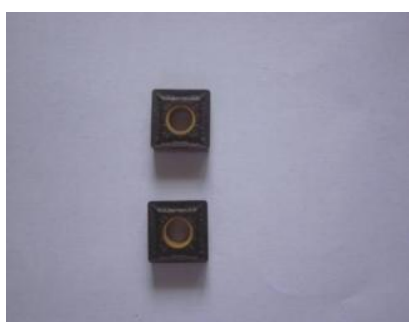

a

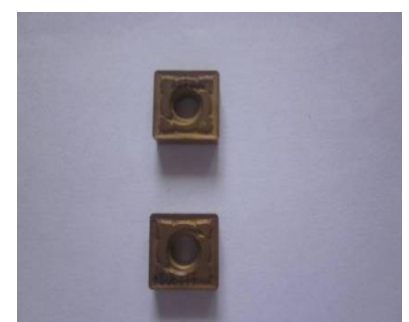

b
Fig. 2 a) Multilayer $\left(\mathrm{TiN}+\mathrm{TiCN}+\mathrm{Al}_{2} \mathrm{O}_{3}\right)$ coated carbide insert b) TiN coated carbide insert

\subsection{Machining Process}

The experiments were performed on a Midas $8 \mathrm{i}$ CNC turning (Lathe), Galaxy made, shown in Figure. 3a using grey cast iron cylinder liner of length is $140 \mathrm{~mm}$ and diameter of $80 \mathrm{~mm}$. All tests were carried out in wet conditions. Two different cutting tool materials and three different cutting speeds and Feed rates (f) were employed throughout the experiments. Depth of cut (doc) was kept fixed at $1.5 \mathrm{~mm}$. Experimental were performed under different cutting conditions shown in Table.2. The 
effects of cutting speed $\left(\mathrm{V}_{\mathrm{c}}\right)$, feed rate (f), and depth of cut $(\mathrm{doc})$ on tool life, surface roughness $\left(\mathrm{R}_{\mathrm{a})}\right.$, and Cycle time and number of components per edge were investigated for different parameters.

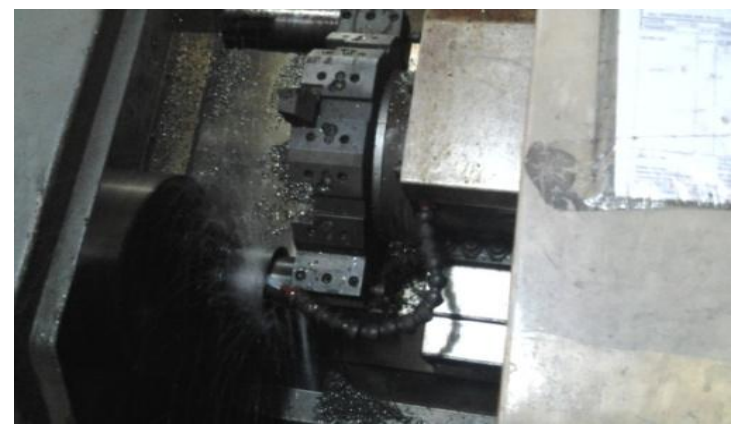

Fig. 3: Machining process

\subsection{Tool Life and Productivity plan}

In this work tool life estimation involves a number of tests to be carried out at various cutting conditions till the failure of tool. Tool life was measured by considering number of components produced before changing (corner burnt or fracture) the cutting edge of the insert and total machined length. Tool is measured in terms of minute. Productivity rate were investigated by considering current existing condition in industry, proposed planed condition. It was investigated by varying three different speed and feed rates using two different coated tools.

Tool life $(\mathrm{T})=$ Machining length $\mathrm{x}$ No of components produced / edge

Table- 2 Experimental cutting conditions

\begin{tabular}{|c|c|c|c|}
\hline Factors & \multicolumn{3}{|c|}{ Levels } \\
\hline Speed $\left(\mathrm{V}_{\mathrm{c}}\right), \mathrm{m} / \mathrm{min}$ & 100 & 125 & 150 \\
\hline Feed (f), mm/rev & 0.25 & 0.3 & 0.35 \\
\hline
\end{tabular}

\section{RESULTS AND DISCUSSION}

The results reported in the Table 3 and 4 were obtained as total machined length of the cylinder block in order to determine the tool life. Results were analyzed with different experiments carried out on grey cast iron with different cutting parameters for two different cutting tool materials.

\subsection{Effect of Feed rates on Tool life}

Fig. 4 shows, the comparative results of tool life for two different tool materials. According to Fig. 4 it can be observe that, performance of tool materials under different cutting conditions. At high speed and feed rate performance of the TiN coated carbide tool is less compare to the multilayer coated tool.

Tool life estimation carried out at various cutting conditions till the insert corner failure. To compare the performance of the different tool materials under different cutting conditions, machining process were carried out till the tool failure and actual machined length. According to table it can be observed that at speed $100 \mathrm{~m} / \mathrm{min}$ and feed $0.25 \mathrm{~mm} / \mathrm{rev}$ total machined length is $5.48 \mathrm{~m}$. This is due to, less vibration, at lower speed and feed rate which result better tool life but less material removal rate it can be attributes that, low cutting speed decreases chip curl radius increases chip thickness larger forces and stresses to deform the material in the cutting zone [1]. As in case of higher feed rate the tool life was decreased. It was seen from the Figure at feed rate $0.35 \mathrm{~mm} / \mathrm{rev}$, for all corresponding speeds, decreased in tool life that is below $25 \mathrm{~min}$, machined length which was less than $3 \mathrm{~m}$. It can be explain increase in feed rate, leads to decreases tool life, due to high feed rate it increases vibration and heat, as a result larger cutting forces and stresses developed on cutting edge which results corner fracture (Broken) shown in fig $5 \mathrm{~b}$ and $5 \mathrm{c}$, Cutting tools fail either by a gradual and progressive wearing of its edge or due to chipping or plastic deformation [4]. Another parameter that is often ignored is tool vibration. It is well known that vibration and chatter are important problems those degrade the part quality and the tool performance [5].

Table-3 Tool life results for single layer coated carbide tool

\begin{tabular}{|c|c|c|c|c|c|}
\hline $\begin{array}{c}\text { Sl. } \\
\text { No }\end{array}$ & $\begin{array}{c}\text { Speed } \\
\left(\mathrm{V}_{\mathrm{c}}\right), \\
\mathrm{m} / \mathrm{min}\end{array}$ & $\begin{array}{c}\text { Feed } \\
(\mathrm{f}), \\
\mathrm{mm} / \mathrm{rev}\end{array}$ & $\begin{array}{c}\text { Depth } \\
\text { of cut } \\
(\mathrm{doc}), \\
\mathrm{mm}\end{array}$ & $\begin{array}{c}\text { Machined } \\
\text { length(l), } \\
\mathrm{m}\end{array}$ & $\begin{array}{c}\text { Tool Corner failure } \\
\text { mode }\end{array}$ \\
\hline 1 & 100 & 0.25 & 1.5 & 5.48 & Corner broken \\
\hline 2 & 100 & 0.3 & 1.5 & 2.8 & Corner broken \\
\hline 3 & 100 & 0.35 & 1.5 & 1.37 & Corner broken \\
\hline 4 & 125 & 0.25 & 1.5 & 5.48 & Corner chip off \\
\hline 5 & 125 & 0.3 & 1.5 & 8.53 & Corner burnt \\
\hline 6 & 125 & 0.35 & 1.5 & 3.69 & Corner broken \\
\hline 7 & 150 & 0.25 & 1.5 & 8.22 & Corner chip off \\
\hline 8 & 150 & 0.3 & 1.5 & 7.9 & Corner burnt \\
\hline 9 & 150 & 0.35 & 1.5 & 1.64 & Corner broken \\
\hline
\end{tabular}


Table- 4 Tool life results for Multi layer coated carbide tool

\begin{tabular}{|c|c|c|c|c|c|}
\hline $\begin{array}{c}\text { Sl. } \\
\text { No }\end{array}$ & $\begin{array}{c}\text { Speed } \\
\left(\mathrm{V}_{\mathrm{c}}\right), \\
\mathrm{m} / \mathrm{min}\end{array}$ & $\begin{array}{c}\text { Feed } \\
(\mathrm{f}), \\
\mathrm{mm} / \mathrm{rev}\end{array}$ & $\begin{array}{c}\text { Depth } \\
\text { of cut } \\
(\mathrm{doc}), \\
\mathrm{mm}\end{array}$ & $\begin{array}{c}\text { Machined } \\
\text { length(l), } \\
\mathrm{m}\end{array}$ & $\begin{array}{c}\text { Tool Corner failure } \\
\text { mode }\end{array}$ \\
\hline 1 & 100 & 0.25 & 1.5 & 6.57 & Corner broken \\
\hline 2 & 100 & 0.3 & 1.5 & 4.10 & Corner broken \\
\hline 3 & 100 & 0.35 & 1.5 & 2.74 & Corner broken \\
\hline 4 & 125 & 0.25 & 1.5 & 16.44 & Corner burned \\
\hline 5 & 125 & 0.3 & 1.5 & 9.31 & Corner broken \\
\hline 6 & 125 & 0.35 & 1.5 & 3.836 & Corner broken \\
\hline 7 & 150 & 0.25 & 1.5 & 15.48 & Corner burnt \\
\hline 8 & 150 & 0.3 & 1.5 & 12.05 & Corner broken \\
\hline 9 & 150 & 0.35 & 1.5 & 5.40 & Insert broken \\
\hline
\end{tabular}

It was observed from the table, increased in machining length of $8.53 \mathrm{~m}$ at feed rate of $0.3 \mathrm{~mm} / \mathrm{rev}$ and speed $125 \mathrm{~m} / \mathrm{min}$, and tool life is $69 \mathrm{~min}$. While machining grey cast iron, due to its brittle property chip contact between tool edge and workpiece is less which produces continuous chips. Tool life is directly related to the work material, cutting tool material, and cutting condition used while machining. As the feed rate increases to $0.35 \mathrm{~mm} / \mathrm{rev}$, with all respective speeds tool life is decreases due to rapid movement which causes the chattering and rubbing action it generate high pressure that are exerted on the chip-tool interface and tool-workpiece generate wear, also high temperature at primary and secondary zone, it loses strength of the cutting point and which results less tool life.

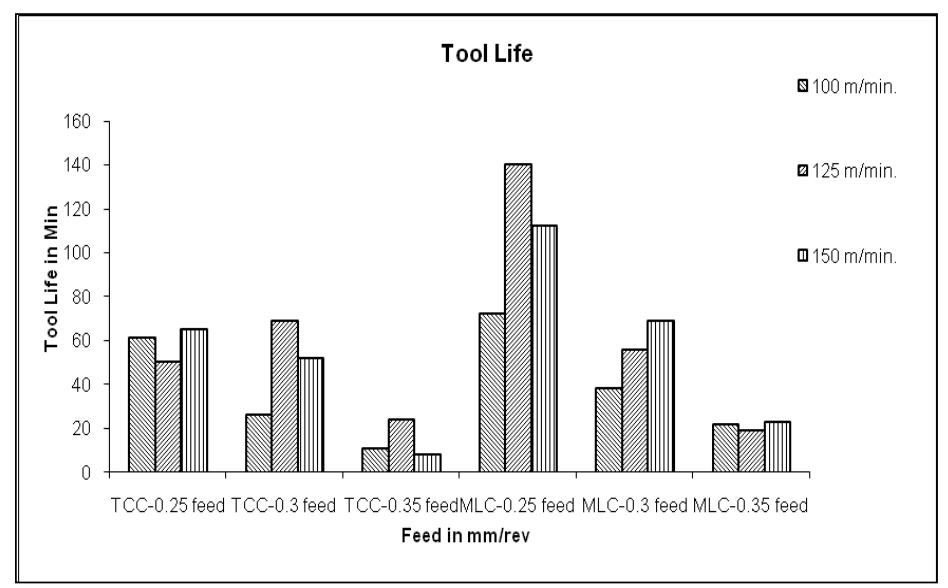

Fig. 4: Effect of Feed rates on tool life for Single layer coated tool and Multilayer coated tool.
Table shows the experimental results of tool life by considering actual machining length, where using multilayer coated tool. It can be seen from the table Failure of the tool after long interval time and total length machined is high when compare to single layer coated tool. Development of new cutting tool materials and availability of machine tools with high rotational speeds have made it possible to increase material removal rate. But at a high cutting speed tool wear occurs more intensively and causes reduction in tool life [11].

It was observed from fig, general trends for higher tool life at all three speeds at feed rate of $0.25 \mathrm{~mm} / \mathrm{rev}$. At speed $125 \mathrm{~m} / \mathrm{min}$ tool life is in increasing trend that is $140 \mathrm{~min}$, total machined length is $16.44 \mathrm{~m}$ shown in table. Also it can be observed tool life is $112 \mathrm{~min}$ at speed of $150 \mathrm{~m} / \mathrm{min}$ and machined length is $15.48 \mathrm{~m}$. This can be explained due to high thermal resistance property, wear resistance property and temperature withstanding capacity of multilayer coated tool [7, 8, 14].It is evident that the longer tool life in case of multilayer coated tool as compare to single layer coated tool, due its toughness and lower cutting forces, thus enabling them to perform better at higher cutting conditions [6, 7, 8].Also it can be as tools with CVD - Ti ( C, N)/Al2O3/TiN coated carbide tools indicate higher resistance to abrasive wear and they can be recommended to roughing operation [9] . The wear initially starts with faster rate caused by micro chipping at the sharp cutting edge (edge failure), also intensive pressure and dynamic loading on cutting edges which leads to tool fracture (broken) shown in Fig 5d.

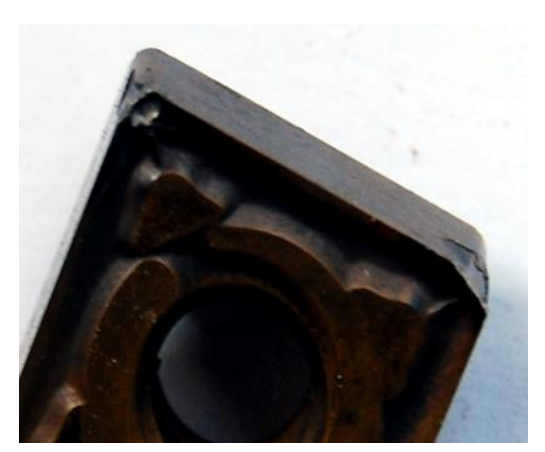

a

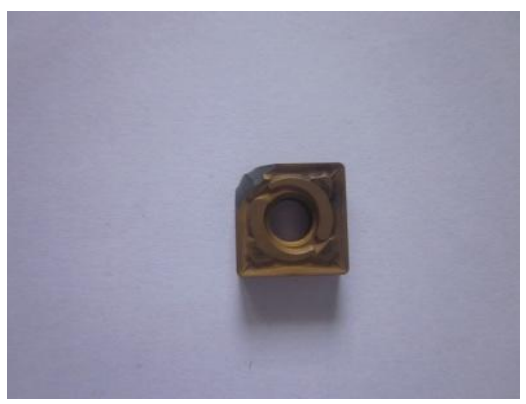

b 

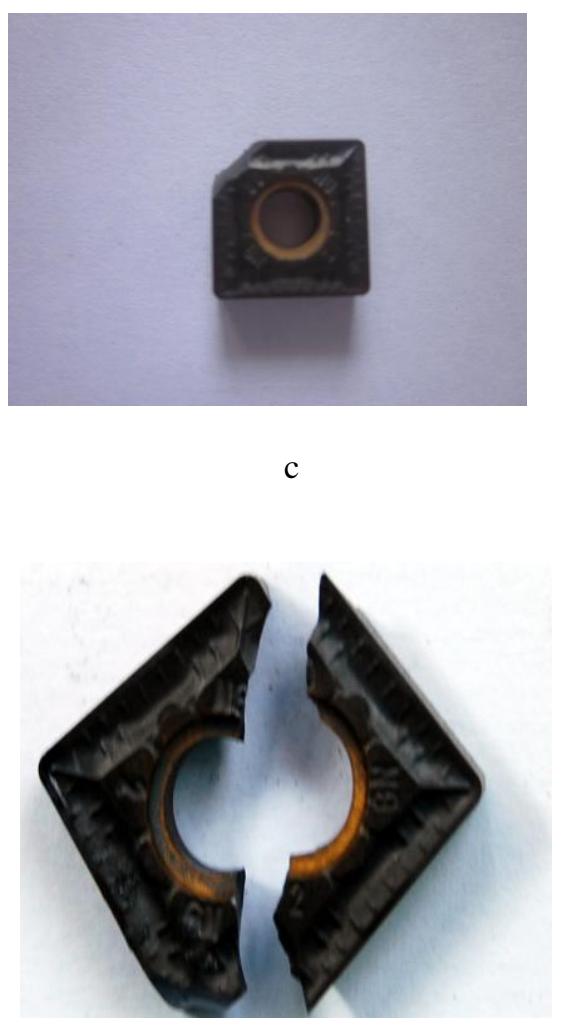

d

Fig. 5: Tool corner failure mode

\subsection{Effect of Feed rates on Productivity}

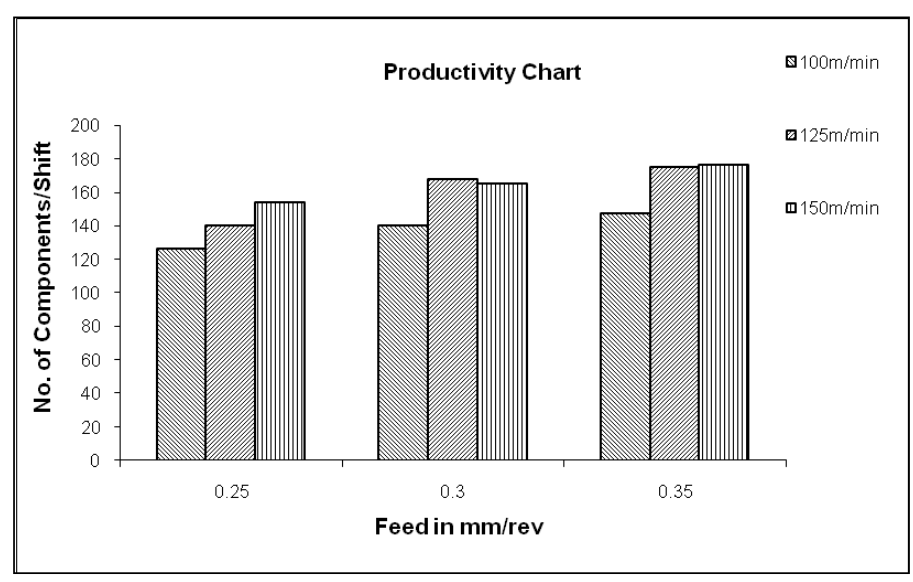

a

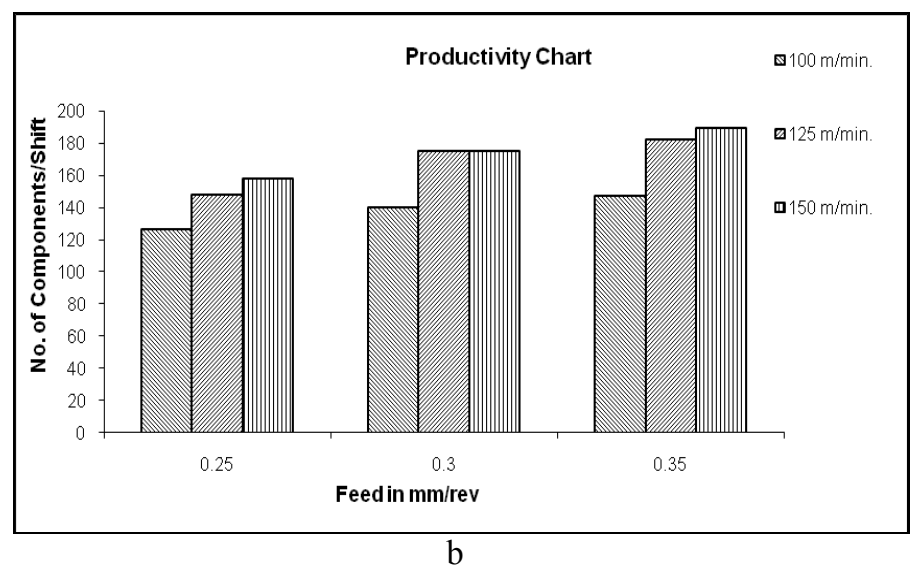

Fig. 6: Effect of Feed rates on Productivity

a. Single layer coated tool $b$. Multilayer coated tool

It can be seen from the fig $6 a$ and fig $6 \mathrm{~b}$, effect of feed rates on productivity. Increasing in the productivity rate with increasing the feed rate and speed. As the feed increases, this leads to increases the components per unit time. At high speed and feed rate material removal rate is high with minimum cycle time.

According to experimental results shown in table it is clear that, the productivity rate is in increasing trend at higher feed rate and speed. It can be explained due to the decreasing in cycle time or processing time leads to increases in the productivity rate. In order to attaining this goal is to gain a more productivity with less cycle time and good tool life.

According to Fig. $6 \mathrm{~b}$ it can be observed that, compare to single layer coated tool, productivity rate is in increasing trend where using multilayer coated tool. At high feed rate and speed, components per shift is in the range of 170 to 180 no. This can be explained that, the properties like high wear resistance and toughness of multi layer coated tool. Some time tool life is also factor which effect on productivity. Tool changing time which leads to the less productivity. According to results, tool changing time is less in case of multilayer coated tool compare to single layer coated tool, due to the failure of tool is after long period of time. Thus the purpose of development of cutting tool material has different advantages such as reducing the manufacturing cost and lead time, machining more difficult materials, moving to unmanned machining operations, improving surface integrity and achieving high metal removal rates [2].

According to productivity calculation given below, it was evident that percentage of improvement in production rate by considering current existing condition in industry, proposed condition. It was investigated by varying three different speed and feed rates using two different coated tools. Finally it was clear that, Modern cutting tools allow cutting at high speeds, thus increasing the volume of chips removed per unit time and this objective requires better management of the machining system corresponding to cutting tool-machine-workpiece 
combination to go towards more rapid metal removal rate. Exploring higher cutting speed depends to a greater extend on the cutting tool materials [2]. Development of tool material plays very vital role to achieve this objective and to cope up with high speed cutting [2].

\subsection{Productivity Calculation}

In present work productivity is calculated by considering overall operation time taken during boring of cylinder block. Also the percentages of productivity were determined by considering the current existing production rate per shift with corresponding cutting conditions. Present existing condition is considered as reference range $(100 \%)$. By changing the cutting conditions it can be obtained the high productivity.

\subsubsection{Steps for calculating the productivity}

1. Initial diameter of job $=\varnothing 80 \mathrm{~mm}$

2. Final diameter of job $=\varnothing 85.5 \mathrm{~mm}$

3. Length of the job $\mathrm{L}=137 \mathrm{~mm}$

4. Total machining length $=137+3=140 \mathrm{~mm}$ ( $3 \mathrm{~mm}$ clearance)

5. Total no of cuts $=2$ cuts

6. First cut $=1.5 \mathrm{~mm}$

7. Second cut $=1.25 \mathrm{~mm}$

a) Rough boring operation (CNC)

Speed $\left(\mathrm{V}_{\mathrm{c}}\right)=100 \mathrm{~m} / \mathrm{min}, 125 \mathrm{~m} / \mathrm{min}, 150 \mathrm{~m} / \mathrm{min}$

Feed rate $(\mathrm{f})=0.25 \mathrm{~mm} / \mathrm{rev}, 0.3 \mathrm{~mm} / \mathrm{rev}, 0.35 \mathrm{~mm} / \mathrm{rev}$

Depth of cut $($ doc $)=1.5 \mathrm{~mm}$ (constant)

b) Finish boring operation (CNC)

Speed $\left(\mathrm{V}_{\mathrm{c}}\right)=125 \mathrm{~m} / \mathrm{min}$

Feed $(\mathrm{f})=0.22 \mathrm{~mm} / \mathrm{rev}$

Depth of cut $(\mathrm{doc})=1.25 \mathrm{~mm}$

Total cycle time $=\mathrm{Tm}_{1}+\mathrm{Tm}_{2}+\mathrm{T}_{\mathrm{c}}+$ loading $\&$ unloading time

$\mathrm{Tm}_{1}=$ Rough boring operation time

$\mathrm{Tm}_{2}=$ Finish boring time

$\mathrm{T}_{\mathrm{c}}=$ Tool changing time $=10 \mathrm{sec}$, and

Loading \& unloading time $=10 \mathrm{sec}$

b) Finish boring operation (Constant)

Speed $\left(V_{c}\right)=125 \mathrm{~m} / \mathrm{min}, \quad$ Feed $(\mathrm{f})=0.22 \mathrm{~mm} / \mathrm{rev}$,

$\operatorname{DOC}(\mathrm{doc})=1.25 \mathrm{~mm}$

Machining time $\left(\mathrm{Tm}_{2}\right)=1 \mathrm{~m} 25 \mathrm{sec}(85 \mathrm{sec})$

\section{Rough boring operation time calculation}

Current existing conditions

Speed $\left(V_{c}\right)=125 \mathrm{~m} / \mathrm{min}$, Feed $(\mathrm{f})=0.25 \mathrm{~mm} / \mathrm{rev}$,

Depth of cut $($ doc $)=1.5 \mathrm{~mm}$

Machining time $=1 \mathrm{~m} 15 \mathrm{sec}(75 \mathrm{sec})$

Total time $=\mathrm{Tm}_{1}+\mathrm{Tm}_{2}+\mathrm{T}_{\mathrm{c}}+$ loading $\&$ unloading time

$$
=75+85+10+10:-180 \mathrm{sec}(3 \mathrm{~min})
$$

No of components per hour $=20$ no's.

No of components per shift $=20 \times 7 \mathrm{hr}=1$ 140no's.

\subsubsection{Percentage of productivity improvement}

Percentage of improvement in productivity is calculated as given below

Productivity percentage (\%) is

Proposed production / Current Existing production

Current existing production $=140 . \mathrm{no} / \mathrm{shift}$

(At $\mathrm{V}_{\mathrm{c}}=125 \mathrm{~m} / \mathrm{min}, \mathrm{f}=0.3 \mathrm{mmrev}$ )

Proposed production $=168 \mathrm{no} / \mathrm{shift}$

(Cocidered $\mathrm{V}_{\mathrm{c}}=125 \mathrm{~m} / \mathrm{min}, \mathrm{f}=0.3 \mathrm{mmrev}$ )

Rate of improvement

Proposed production - Current existing production

$168-140=28$ no's.

Percentage of improvement in productivity

$28 * 100 / 140$

$20 \%$

Table-5 Optimized parameters for different tool materials

\begin{tabular}{|c|c|c|c|c|c|c|}
\hline \multirow[b]{2}{*}{$\begin{array}{l}\text { Sl. } \\
\text { No }\end{array}$} & \multirow[b]{2}{*}{$\begin{array}{c}\text { Speed } \\
\left(\mathrm{V}_{\mathrm{c}}\right), \\
\mathrm{m} / \mathrm{min}\end{array}$} & \multirow[b]{2}{*}{$\begin{array}{c}\text { Feed } \\
\text { (f), } \\
\mathrm{mm} / \mathrm{rev}\end{array}$} & \multicolumn{2}{|c|}{ TCC (Tool 1) } & \multicolumn{2}{|c|}{ MLC(Tool 2) } \\
\hline & & & $\begin{array}{c}\text { Tool } \\
\text { life (T), } \\
\text { min }\end{array}$ & $\begin{array}{c}\text { Productivity } \\
(7 \mathrm{hr})\end{array}$ & $\begin{array}{l}\text { Tool } \\
\text { life } \\
(\mathrm{T}), \\
\text { min }\end{array}$ & $\begin{array}{c}\text { Productivity } \\
(7 \mathrm{hr})\end{array}$ \\
\hline 1 & 100 & 0.25 & 61 & 126 & 72 & 126 \\
\hline 2 & 100 & 0.3 & 26 & 140 & 38 & 140 \\
\hline 3 & 100 & 0.35 & 11 & 147 & 22 & 147 \\
\hline 4 & 125 & 0.25 & 50 & 140 & 140 & 148 \\
\hline 5 & 125 & 0.3 & 69 & 168 & 56 & 175 \\
\hline 6 & 125 & 0.35 & 24 & 175 & 19 & 182 \\
\hline 7 & 150 & 0.25 & 65 & 154 & 112 & 158 \\
\hline 8 & 150 & 0.3 & 52 & 165 & 69 & 175 \\
\hline 9 & 150 & 0.35 & 8 & 176 & 23 & 189 \\
\hline
\end{tabular}

The summarized values for the single layer coated tool material are as depicted in Table.5. From the table it can be observed that, the combination of tool life and the productivity are at their optimum rates.

It can be observed from table 5 that, the appropriate parameters in order to obtain better tool life, productivity, and minimum surface roughness. The results of the appropriate parameters are presented in the following paragraphs. 
As the speed increases, the material removal rate also increases. At high speed, the surface roughness is minimum with low feed rate. According to results it can be observe that, at speed $150 \mathrm{~m} / \mathrm{min}$ and feed rate $0.25 \mathrm{~mm} / \mathrm{rev}$, increasing in tool life and productivity rate compare to currant existing condition. On other hand surface roughness, it can be obtained within the recommended range $(4 \mu \mathrm{m})$. In order to obtain the better tool life and productivity appropriate cutting conditions for TiN coated carbide tool is: Speed $125 \mathrm{~m} / \mathrm{min}$ and feed $0.3 \mathrm{~mm} / \mathrm{rev}$ and speed $150 \mathrm{~m} / \mathrm{min}$, feed $0.3 \mathrm{~mm} / \mathrm{rev}$.

The summarized values for the multi layer coated tool material are as depicted in Table.5. From the table it can be observed that, the combination of tool life and the productivity are at their optimum rates.

According to the experimental results, it was clear that, for the higher speed values, the tool life and productivity is high. Whereas the surface roughness is also obtained within the recommended range. At speed $150 \mathrm{~m} / \mathrm{min}$ and feed rate of $0.25 \mathrm{~mm} / \mathrm{rev}$ and $0.3 \mathrm{~mm} / \mathrm{rev}$, all three existing results are in increasing trend as compare to TiN coated tool. It can be see least surface roughness of $1.94 \mu \mathrm{m}$. with better tool life and productivity rate. This is due to coated carbide tools or multilayer coated carbide tools ensure higher wear resistance, lower heat generation and lower cutting forces, thus enabling them to perform better at higher cutting conditions compared to uncoated counter parts [6]. Based on the experimental results it was evident that the performance of the multilayer coated tool is better as compare to single layer coated tool. Performance Multilayer coated tool is better in order to tool life and productivity as compare to single layer coated tool and uncoated tool .This indicates that the titanium nitride (TiN) coating on alumina $\left(\mathrm{Al}_{2} \mathrm{O}_{3}\right)+$ titanium carbonitride $(\mathrm{TiCN})$ multilayer-coated tools helps improving the quality of machined surface $[6,12]$.

\section{CONCLUSIONS}

In this study based on the tool materials and cutting parameters following conclusions were presented.

With the help of different experimental work, effect of process parameters on the tool life and productivity has been investigated. The optimal machining conditions have been presented in the following points.

1. The multilayer coating TiN-TiCN- $-\mathrm{Al}_{2} \mathrm{O}_{3}$ perform superior compare to single layer coated tool, they can be recommended to machine grey cast iron cylinder blocks.

2. Increasing the feed rate of $0.35 \mathrm{~mm} / \mathrm{rev}$ increase the tool failure with all three speeds with two coated tools.

3. At high cutting speed and feed rate tool life is maximum from multilayer coated tool compare to TiN coated tool.

4. Productivity rate is also increased with increasing speed and feed rate with less tool wear with multilayer coated tool.
5. Optimized parameter for high productivity and better tool life is at speed $125 \mathrm{~m} / \mathrm{min}, 150 \mathrm{~m} / \mathrm{min}$ and feed $0.25 \mathrm{~mm} / \mathrm{rev}, 0.3 \mathrm{~mm} / \mathrm{rev}$ obtained.

6. Performance of multilayer coated tool is superior compare to TiN coated tool in terms of tool life and productivity.

\section{REFERENCES}

[1]. A Yakup Turgut, Ishan Korgut, Kadir Yavuz, "An experimental investigation in to the machinability of GGG-70 grade spheroidal graphite cast iron, Indian Journal of Engineering and materials sciences.Vol.16,April 2009,pp.116-

[2]. Ashok Kumar Sahoo and Bidyadhar Sahoo, "Surface roughness model and parametric optimization in finish turning using coated carbide insert: Response surface methodology and Taguchi approach, "International Journal of Industrial Engineering Computations, 2, 2011, pp.819-830.

[3]. Atanda P, Okeowo, Oluwelo o, "Microstructural study of Heat Treated Chromium Alloyed Grey cast iron", Journal of materials Characterization and processing, Vol. 9, No.3, 2010, pp.263-274.

[4]. Bashim A Khidhir, Bashir Mohamed, "Machining of nickel based alloys using different cemented carbide tools", Journal of Engineering science and technology, vol 5, No 3, 2010, pp.264-271.

[5]. Erol Zeren ,Tugrul O” zel · Tsu-Kong Hsu • " Effects of cutting edge geometry, workpiece hardness, feed rate and cutting speed on surface roughness and forces in finish turning of hardened AISI H13 steel, Int J Adv Manuf Techno (2005) 25: 262-269. DOI 10.1007/s00170-003-1878-5.

[6]. Ezugwu E.O, Soh.K.S, "Wear of coated carbide tool when machining a Ni-Cr-Mo (817) steel", Lubrication Engineering, 1997.

[7]. Ghani.J.A, Choudhury.I.A, Masjuki.H.H. "Wear mechanism of TiN coated carbide and uncoated cermets tools at high cutting speed applications", Journal of Materials Processing technology, Vol 153-154, 2004, pp.1067-1073.

[8]. Gunay.M, Aslan.E, Korkut.I, Seker.U, "Investigation of the effect of rake angle on main cutting force." International Journal of Machine Tools and Manufacture, Vol 44, 2004, pp. 953-959.

[9]. Grzegorz Krolczyk, "effect of the cutting parameters impact on tool life in duplex stainless steel turning process, "Original scientific paper, ISSN 1330-3651. UDC/UDK 620.178.1: [621.941.025:669.14].

[10]. Khan.A.A, Hajjaj.S.S, "Capabilities of Cermets Tools for High Speed Machining of Austentic Stainless Steel”, Journal of Applied Sciences ,Vol 6 (4), 2006,pp. 779-784.

[11]. K.V.Santha Kumari, Dipak Ranjan Jana and Ajani Kumar. "Effects of tool setting on tool cutting angle on turning operation,"ARPN Journal of Engineering and Applied Sciences, vol 5 No 5, MAY 2010.

[12]. Recep YiGiT, Fehim FINDIK, Erdal CELIK, "Performance of multilayer coated carbide tools when turning cast iron", Turkish J.Eng Env.Scince,Vol 33,2009,147-157.

[13].Thamizhamanii.S, Hassan.S, "Analyses of roughness, forces and wear in turning Grey cast iron", Journal of 
Achievements in Materials and Manufacturing Engineering,

Vol. 17, 2006, Issue 1-2 July-Aug.

[14]. Thandra S.K., Choudhury S.K "Effect of process parameters on cutting force, surface finish and tool wear in hot machining", International Journal of machining and machinability of materials, Vol 7, No 3/4, pp.260-273,2010.

\section{BIOGRAPHIES}

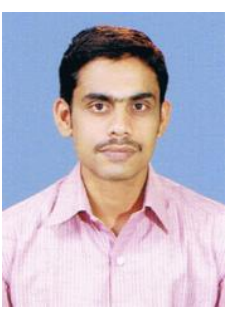

Prasanna.P.Kulkarni

Presently working as lecturer

From past 2 years in Mechanical

Engineering Department. Also having

1 year experience in tooling industries.

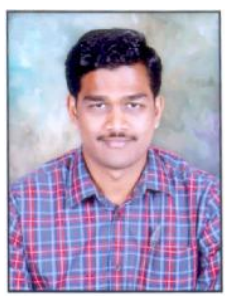

\section{Hemanth kumar K.S}

Presently working as lecturer from past 3 years in Mechanical engineering Department.Also having 6months experience in tooling industry.

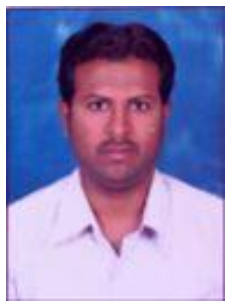

\section{Vinayak koppad}

Presently working as lecturer from past 3years in Mechanical engineering Department. 